\title{
Antibodies anti Bloodstream and Circumsporozoite Antigens (Plasmodium vivax and Plasmodium malariae/P. brasilianum) in Areas of Very Low Malaria Endemicity in Brazil
}

\author{
Izilda Curado/ ${ }^{+}$, Ana Maria RC Duarte*, Altaf A Lal**, Salma G Oliveira***, \\ Judith K Kloetzel $* * * * *$
}

\begin{abstract}
Laboratório de Imunopatologia, Instituto Butantan, Av. Vital Brasil 1500, 05503-900 São Paulo, SP, Brasil *Instituto de Medicina Tropical de São Paulo, Av. Enéas de Carvalho Aguiar 470, 05403-000 São Paulo, SP, Brasil **Malaria Division, Parasitic Diseases, National Center for Infectious Diseases, Centers for Diseases Control and Prevention, Atlanta, GA 3041-3717, USA ***Instituto Evandro Chagas, Av. Almirante Barroso 492, 66090-000 Belém, PA, Brasil ****Departamento de Parasitologia, Instituto de Ciências Biomédicas, USP, Av. Lineu Prestes 1374, 05508-900 São Paulo, SP, Brasil
\end{abstract}

During 1992-1994, 33 malaria cases were reported in two regions in Brazil where few sporadic atypical cases occur, most of them in home owners, who are weekenders, while home caretakers live there permanently. Indirect Fluorescent Antibody Test (IFAT), with Plasmodium vivax, and Enzime Linked Immunosorbent Assay (ELISA) with repeat peptides of the circumsporozoite (CS) proteins of the 3 known $\mathrm{P}$. vivax variants and $\mathrm{P}$. malarie/P. brasilianum, were performed on 277 sera, obtained within a 5 to $10 \mathrm{~km}$ range of malaria cases. Very rarely did any of these donors recall typical malaria episodes. Blood smears of all but 5 were negative. One of the 5 malaria cases included in our serology was of a home owner, 1 of a permanent resident, 3 from Superintendência de Controle de Endemias employees who went there to capture mosquitoes. In Region 1 the prevalence of IFAT positive sera was $73 \%$ and $28 \%$ among caretakers, $18 \%$ and $9.6 \%$ among home owners. In Region 2 (3 localities) no distinction was possible between caretakers and home owners, IFAT positivity being $38 \%, 28 \%$ and $7 \%$. The relative percentage of positive anti-CS repeats ELISA, differed for each of the peptides among localities. Dwellings are in the vicinity of woods, where monkeys are frequently seen. The origin of these malaria cases, geographical differences and high seropositivity is discussed.

Key words: malaria serology - Plasmodium vivax - Plasmodium vivax VK247 - human Plasmodium vivax-like Plasmodium malariae/P. brasilianum - circumsporozoite protein - Brazil

Malaria is an important endemic disease in Brazil. After having been controlled to a major extent in the forties and fifties, its incidence has been increasing since the sixties. In 1970, 52,000 cases of malaria were recorded, rising to 400,000 cases in 1985 (Tauil 1986). In 1992, a total of 577,098 malaria cases were officially recorded in Brazil, 99.3\% of these coming from the Amazon region. In 1993 total dropped to 483,367 cases, numbers rising again to former levels in 1994 - 568,300 (Marques \& Gutierrez 1994, SUCEN 1995).

In the State of São Paulo, since the sixties, more than $90 \%$ of the malaria cases occur in patients

\footnotetext{
Work supported by CNPq, LIM 49 - Laboratórios de Investigação Médica HCFMUSP.

${ }^{+}$Corresponding author. Fax: +55-11-813.7222 (extension 2162)

Received 24 June 1996

Accepted 6 November 1996
}

coming from the Amazon region. However every year there are a few autochtonous cases, diagnosed as being due to Plasmodium vivax, some of them with atypical, very mild and transitory clinical symptoms. These present low parasitaemia, of very short duration, frequently clearing even before a treatment can be initiated (Carvalho et al. 1988). These malaria cases are generally concentrated in a few foci, part of them located in the Vale do Ribeira and at the Serra do Mar (Carvalho et al. 1988, SUCEN 1990).

Anopheles (Kerteszia) cruzii and An. (Ker.) bellator have been incriminated as the local vectors (Forattini et al. 1986, Wilkerson \& Peyton 1991). These anophelines are known to transmit human malaria parasites, as well as those of simian malaria: $P$. simium and $P$. brasilianum. Monkeys of the genus Allouata and Cebus, live in forests of this region (Deane 1992). P. simium was first described by Flávio da Fonseca, in a howlermonkey (Alouatta fusca) from São Paulo. The 
morphology of this parasite resembles $P$. vivax (Deane 1988); a monoclonal antibody directed against the circumsporozoite (CS) repeat of $P$. vivax reacts with P.simium sporozoites (Qari et al. 1993). Seven CS clones of $P$. simium had a CS repeat similar to classic $P$. vivax, and two, to the variant $P$. vivax VK247 (Goldman et al. 1993).

The present study was undertaken as a serological survey of populations living in areas where malaria cases were reported recently, to evaluate the prevalence of antibodies against $P$. vivax blood forms and against the repeats of CS protein of the three known forms of the repeats of these proteins of "classic" $P$. vivax, $P$. vivax VK247, human $P$. vivax-like/P. simiovale and of $P$. malariae/P. brasilianum.

\section{MATERIALS AND METHODS}

Study area - Several localities in two districts in the State of São Paulo were studied.

In Region 1, Vale do Ribeira, district of Juquitiba, two closely situated localities, Shangrilá and Juquiazinho were included (Fig. 1A). They are situated in a rural area, about $60 \mathrm{~km}$ south of São Paulo, along the highway BR 116. Juquiazinho is located about $10 \mathrm{~km}$ south of Shangrilá. Small rural properties are mostly used on weekends by home owners, while their home caretakers live there permanently. There are about 110 properties in Juquiazinho. The 85 houses in Shangrilá are of a higher standard. In both localities properties are surrounded by primary and secondary woods of Mata Atlântica, where the presence of monkeys has been reported. Both weekenders and the permanent inhabitants frequently hunt, fish and gather wood in the forest. Most of the few autochtonous malaria cases registered in the area are of home owners, while the permanent population does not recall ever having presented symptoms of clinical malaria.

In Region 2, Serra do Mar, in the mountains, close to the beach, in the district of São Vicente, the localities that we investigated are Pai Mathias and Evangelista de Souza, situated along the railway connecting São Vicente to São Paulo (Fig. 1B). Access to these localities is only by infrequently running trains. These two localities are situated at an altitude of $800 \mathrm{~m}$ above sea level and within the primary and secondary woods of Mata Atlântica. The presence of monkeys has also been reported. There are few inhabitants, some employees of the railroad. Most of the houses are only occupied on weekends. In Pai Mathias, there are only 20 properties, and the habitations are improvised shacks. In Evangelista de Souza there are 35 properties and the inhabitantes either work at the railroad or on small plantations. The third locality in this district,
Balneário Esmeralda, is located along a highway, at the foot of the mountain. In this locality there is a cluster of 25 houses, most of them very rustic, built of wood and its inhabitants usually work in the nearby town. At the end of the cluster, crossing a river (Rio Branco), one gets close to the forest, which in turn leads to Serra do Mar, where some houses are located within the woods. People living along the roadside occasionally hunt and fish.

Malaria was quite common at the beginning of this century in all these areas, and an epidemic affected the workers who constructed the railroad leading from São Paulo through the Serra do Mar, at that time (Gadelha 1994).

Blood samples - This study was conducted from 1992 to 1994 . Blood was collected into vacutainer tubes, from adult individuals (15 years old and above - mean 30 years) in an area within 5 to 10 $\mathrm{km}$ of malaria cases notified during that period. These reported cases totaled 4 in the district of Juquitiba. At Serra do Mar, 6 malaria cases were identified during that period in Engenheiro Ferraz, 2 in Pai Mathias and 1 in Balneário Esmeralda, although within a broader area of Serra do Mar, including districts we did not cover in our study, the total amounted to 33 cases. We did not obtain samples of all patients from the area covered by us. Sera were stored at $-20^{\circ} \mathrm{C}$ until used. Thick and thin blood smears, for microscopical observation, were also performed. A questionnaire containing information on activities, clinical symptoms, history of past malaria episodes and travels to malaria endemic areas, was given to each individual. A total of 277 samples were obtained, 274 of these

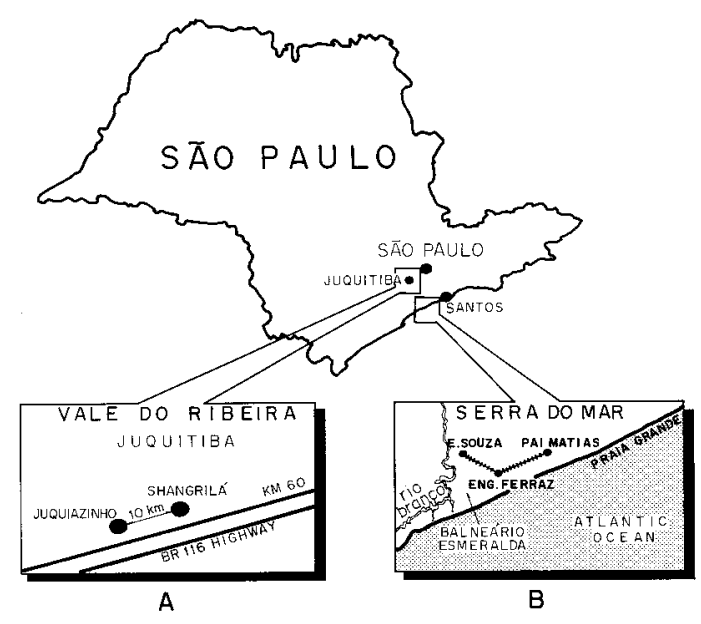

Fig. 1: localization of the study areas. In Vale do Ribeira, km 60 indicates the distance from the city of São Paulo. A. Region 1 - Vale do Ribeira, B. Region 2 - Serra do Mar. 
being collected locally and 3 from workers of Superintendência de Controle de Endemias (SUCEN), who had baited mosquitoes in Pai Mathias. Samples were collected with informed consent of the patients.

\section{Serological tests}

Indirect Fluorescent Antibody Test (IFAT) IFAT was performed according to Ferreira and Sanchez (1988), using $P$. vivax infected erythrocytes as antigen and isothiocyanate conjugated antihuman IgG antibodies (Biolab Diagnóstica SA). Negative and positive controls were included in all assays, positive controls dilutions varying from $1: 40$ to $1: 1280$. The antigen was obtained from a human $P$. vivax malaria case with a first infection. The anti-human IgG isothiocyanate conjugate was tested at several dilutions with known positive and negative sera. A 1:40 serum dilution was determined as being the cut-off point for a positive reaction. At this dilution all of 23 blood bank sera from individuals who had never been in malaria endemic areas were negative.

Enzyme Linked Immunosorbent Assay (ELISA) - ELISA was performed according to Zavalla et al. (1986), with some modifications, using synthetic peptides corresponding to repeats of the circumsporozoite antigen of the "classic" $P$. vivax (Pvc) (Pessi et al. 1990) (DDAAD) 9 , P. vivax VK247 (Pvk) (Rosenberg et al. 1989) $(\text { ANGAGNQPG })_{4}$ and the human $P$. vivax -like (Pvl) (Qari et al. 1993) (APGANQEGGAA) 3 . We also used a synthetic peptide corresponding to repeats of the circumsporozoite antigen of the $P$. malariae/P. brasilianum $(\mathrm{Pm} / \mathrm{Pb})$ (Lal et al. 1988b) $\left[(\mathrm{NAAG})_{4}\right]_{4}$.

Immulon II (Dynatech Laboratories, Chantilly, VI, USA) or NUNC (Inter Med-Roslide-Denmark SA) plates were coated with the peptides, at optimal concentrations, as determined by checkerboard titrations: $5 \mu \mathrm{g} / \mathrm{ml}$ for Pvc and $\mathrm{Pm} / \mathrm{Pb}, 20 \mu \mathrm{g} / \mathrm{ml}$ for Pvk and $10 \mu \mathrm{g} / \mathrm{ml}$ for Pvl. The sera were diluted at 1:50, and peroxidase conjugated anti-human IgG immunoglobulins (SIGMA) and ABTS were used. Reactions were read at $414 \mathrm{~nm}$ in a Multiskan MC/ 340 P minireader. Positive and negative controls were included in each assay. The checkerboard titrations were made for each peptide with 6 sera that reacted with it at different intensities. Sera dilutions were 1:50, 1:100 and 1:200 and peptide concentrations varied from $2.5 \mu \mathrm{g} / \mathrm{ml}$ to $20 \mu \mathrm{g} / \mathrm{ml}$. Two sera from blood-bank donors were included. The concentrations of peptides and serum dilutions chosen were those that gave maximum absorbancy with positive sera, and minimal values with the negative sera. Cut-off values were then determined by processing 43 sera from blood donors from a blood bank in São Paulo, who had never been to a malarious area, and adding three standard deviations to the mean absorbancy obtained.

Statistical analysis - The prevalence of positive reactions in the different groups of serum donors was compared by the chi-square test, optical densities by non-parametric Kruskall-Wallis test and geometric mean titers by ANOVA.

\section{RESULTS}

The results of the serological tests determined in the two different regions, namely, Vale do Ribeira (Region 1) and Serra do Mar (Region 2), are being presented separately. These two regions have distinct geographical, social and physical characteristics and, therefore, the comparison of data of the localities within each region of the two localities, seemed to be most appropriate.

Parasitaemia - Among the blood smears from the 274 non-symptomatic individuals collected by us (148 from Region 1 and 126 from Region 2), one from each region had a positive smear, with a single malaria trophozoite, which resembled $P$. vivax. One of these, a home caretaker of Shangrilá, only complained of a low fever and headache. A follow-up smear after two weeks was negative and his symptoms had disappeared without any treatment. The other patient, a home owner from Pai Mathias did present malaria symptoms and was treated. The 3 remainder positive smears were from people who had captured mosquitoes in Pai Mathias. All of these parasites resembled P. vivax.

Antibodies to $P$. vivax blood stages detected by IFAT

Region 1 - The results obtained by IFAT using $P$. vivax asexual blood stages as antigen, differed considerably among the two localities of Region 1 . The overall prevalence of positive reactions was $21 \%(16 / 77)$ in Shangrilá and 52\% (38/73) in Juquiazinho ( $p<0.001)$ (Fig. 2).

A highly significant difference was found when we compared the prevalence of IFAT positive sera of the home caretakers, with those of home owners. In Juquiazinho $73 \%$ of the sera of home caretakers $(33 / 45)$ were positive when compared to $18 \%(5 / 28)$ of the sera of the home owners ( $<<0.0001)$ (Fig. 3). In Shangrilá, 35\% of home caretakers sera were positive (16/46), compared to $9.67 \%$ (3/31) of home owners (p >0.05) (Fig. 3).

Region 2 - The prevalence of anti-P. vivax asexual stage IgG antibodies was not statistically different between two of the localities, Pai Mathias, [38\% - (10/26)] and Evangelista de Souza [28\% (9/32)]. However the percentage of positivity was significantly lower in the third locality, Balneário Esmeralda [7\% - 5/69 (p<0.001)] (Fig. 4). 


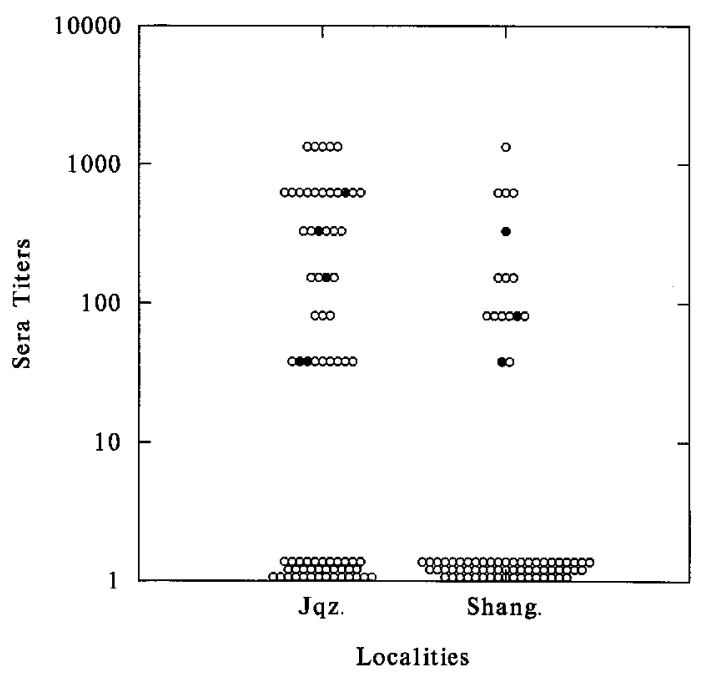

Fig. 2: results of Indirect Fluorescent Antibody Test, using Plasmodium vivax blood stages as antigen. Each circle represents an individual serum from Region 1, localities of Shangrilá (Shang.) (positive sera 16/77 - 21\%) (including one malaria case of a caretaker) and Juquiazinho (Jqz.) (positive sera 38/ $73-52 \%$ ). Home owners (city dwellers) (๑) and home caretakers (permanent residents) (O).The cut-off titer was 1:40.

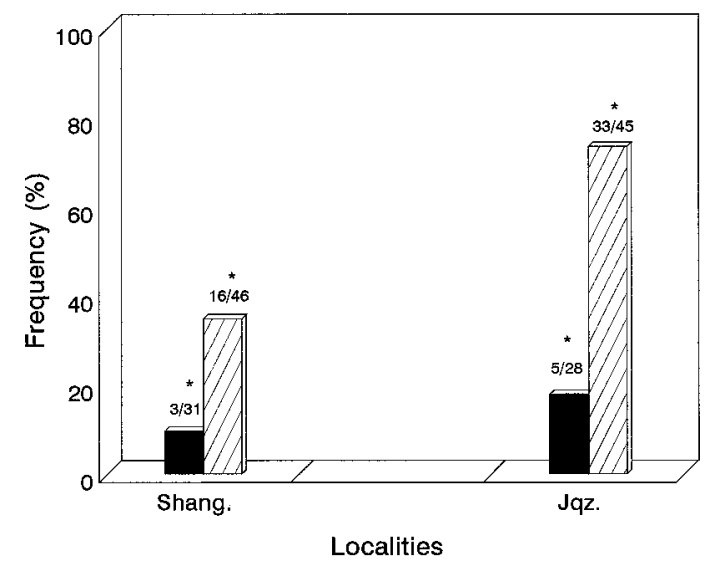

Fig. 3: comparison between home owners (city dwellers) and home caretakers (permanent residents). Results of Indirect Fluorescent Antibody Test reactions, using Plasmodium vivax blood stages as antigen and sera of individuals from Region 1, localities of Shangrilá (Shang.) (including one malaria case of a caretaker), and Juquiazinho (Jqz). The numbers over the individual columns represent the respective positive sera/total examined. The cut-off titer was 1:40. * Significant difference between home owners and home caretakers.

Antibodies against the CS antigen determined by ELISA

Region 1 - All sera were assayed for binding to the 3 known forms of the repeats of the CS protein of $P$. vivax ("classic", VK247 and vivax-like) as well as for binding to the $P$. malariae/P. brasilianum CS repeat. Using the CS repeats as

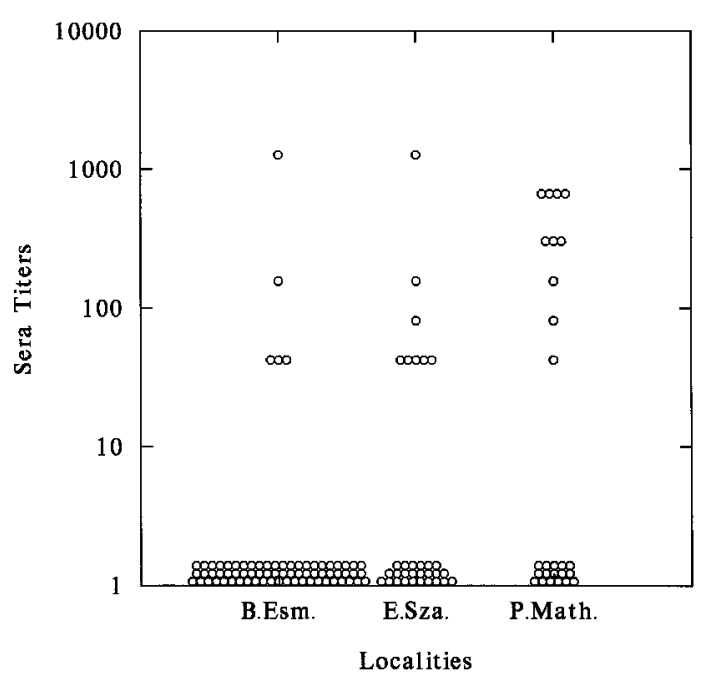

Fig. 4: results of IFAT, using Plasmodium vivax blood stages as antigen. Each circle represents an individual serum from Region 2, localities of Pai Mathias (P. Math.) (positive sera 10/26 - 38\%) (including 1 malaria case of a home owner and 3 of Superintendência de Controle de Endemias employees), Evangelista de Souza (E. Sza.) (positive sera 9/32 - 28\%) and Balneário Esmeralda (B. Esm.) (positive sera 5/69 - 7\%). The cut-off titer was 1:40. B.Esm. significantly different from $P$. Math. and E. Sza.

antigens, we detected a very pronounced difference between the ELISA results of the two localilties. While in Shangrilá 17\% (13/78) of the sera were positive with the $P$. vivax-like repeat, all sera from Juquiazinho were negative to this peptide $(\mathrm{p}<0.001)$. In contrast, only $2.5 \%(2 / 78)$ were positive for $P$. vivax VK247, in Shangrilá, whereas $15 \%(13 / 84)$ of the sera from Juquiazinho had antibodies to this peptide $(\mathrm{p}<0.01)$ (Fig. 5$)$.

The prevalence of anti- $P$. malariae/P. brasilianum antibodies was $2.38 \%(2 / 84)$ and $2.56 \%(3 / 78)$ and of anti-"classic" $P$. vivax CS antibodies, $5.95 \%(5 / 84)$ and $2.56 \%(2 / 78)$ in Juquiazinho and Shangrilá, respectivily (Fig. 5). The data for ELISA positivity and mean absorbancies were also compared for home caretakers and home owners in both of these localities. No significant differences of reactivity with any of the peptides were found among these two groups and this may be accounted for by the small number of ELISA positive sera.

Region 2 - In this area, we also detected differences in the prevalence of positive reactions with the different repeat peptides, in the sera of individuals from the three localities. Reactivity with $P$. malariae/P. brasilianum repeats predominated in Pai Mathias $11 \%$ (3/26), while the prevalence was $1.4 \%$ (1/70) in Balneário Esmeralda, and absent in Evangelista de Souza $(\mathrm{p}<0.05)$. The num- 

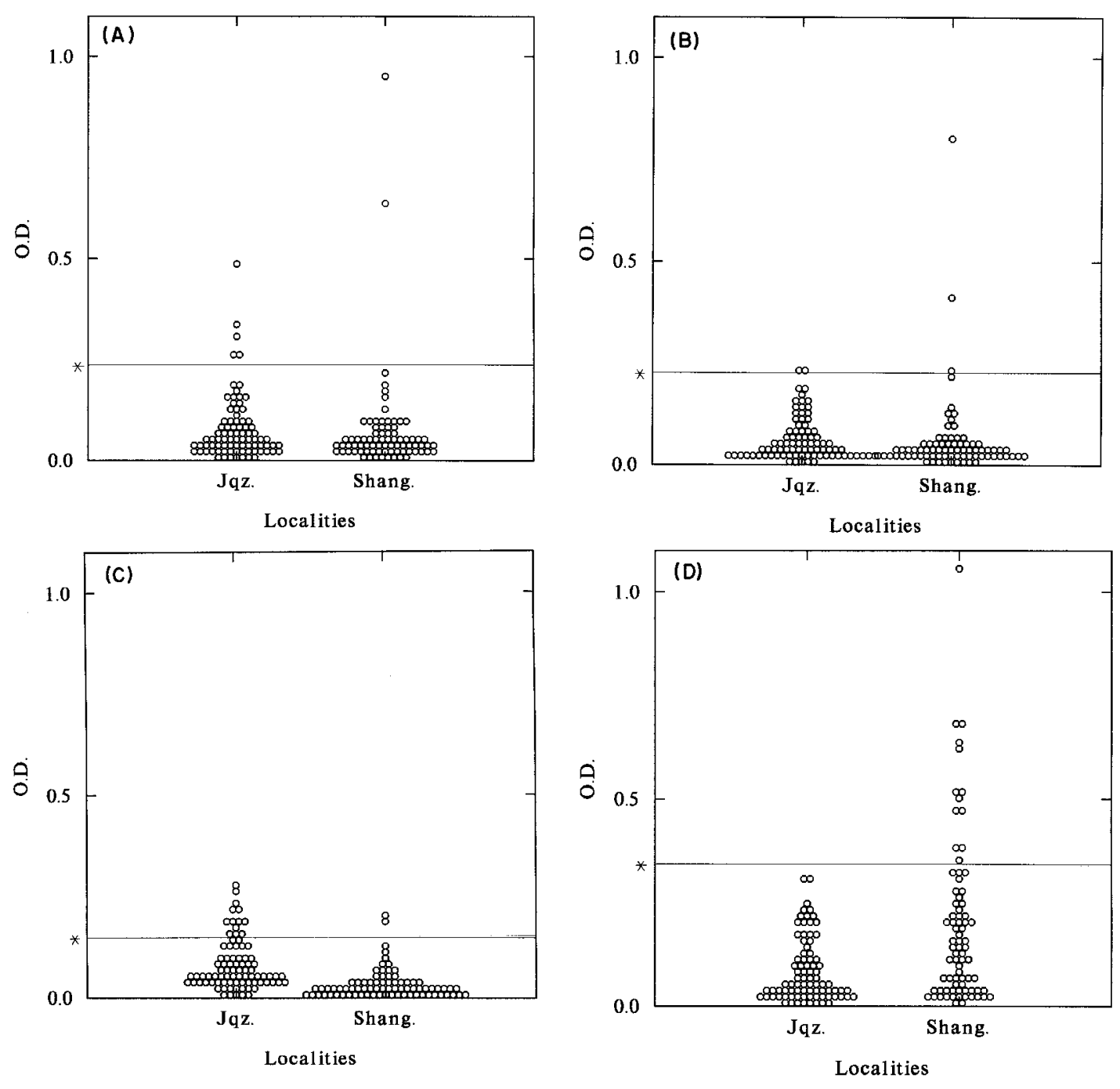

Fig. 5: results of Enzime Linked Immunosorbent Assay using circumsporozoite repeat peptides with the sera from Region 1, localities of Shangrilá (Shang.) and Juquiazinho (Jqz.). Each circle represents an individual serum assayed with peptides of (A) "classic" Plasmodium vivax (positive sera $2 / 78-2.56 \%$ in Shang.; $5 / 84-5.95 \%$ in Jqz.), (B) P. malariae/P. brasilianum (positive sera 3/78 - 2.56\% in Shang.; 2/84 - 2.38\% in Jqz.), (C) P. vivax VK247 (2/78 - 2.5\% in Shang.; 13/84 - 15\% in Jqz.), (D) $P$. vivax-like (Pvl) $(13 / 78-17 \%$ in Shang.). Cut off values are indicated by horizontal lines.

ber of sera reacting with the "classic" $P$. vivax repeats were $4 \%(1 / 26)$ in Pai Mathias, and absent in Evangelista de Souza and Balneário Esmeralda (Fig. 6).

For $P$. vivax VK247, these numbers were $4 \%$ $(1 / 26)$ in Pai Mathias, $2.5 \%$ (1/40) in Evangelista de Souza and 10\% (7/70) in Balneário Esmeralda, while anti- $P$. vivax-like antibodies were only observed in Balneário Esmeralda - 6\% (4/70). The mean absorbancy with any of the peptides did not differ significantly among these localities, but again, this lack of statistical significance may be due to the small numbers of positive sera (Fig. 6).

\section{DISCUSSION}

Considering the very low prevalence of clinical malaria and parasitemia, the prevalence of anti$P$. vivax blood stage antibodies (IFAT) was surprisingly high in all localities here studied, in the State of São Paulo, outside the malaria endemic areas. The only exception was Balneário Esmeralda, where seropositivity was much lower $7 \%(5 / 69)$, as compared to $38 \%(10 / 26)$ and $28 \%$ (9/32) in Pai Mathias and Evangelista de Souza. The prevalence of anti-asexual blood-stage IgG antibodies was much higher in the permanent residents, i.e. the home caretakers, than in the transi- 

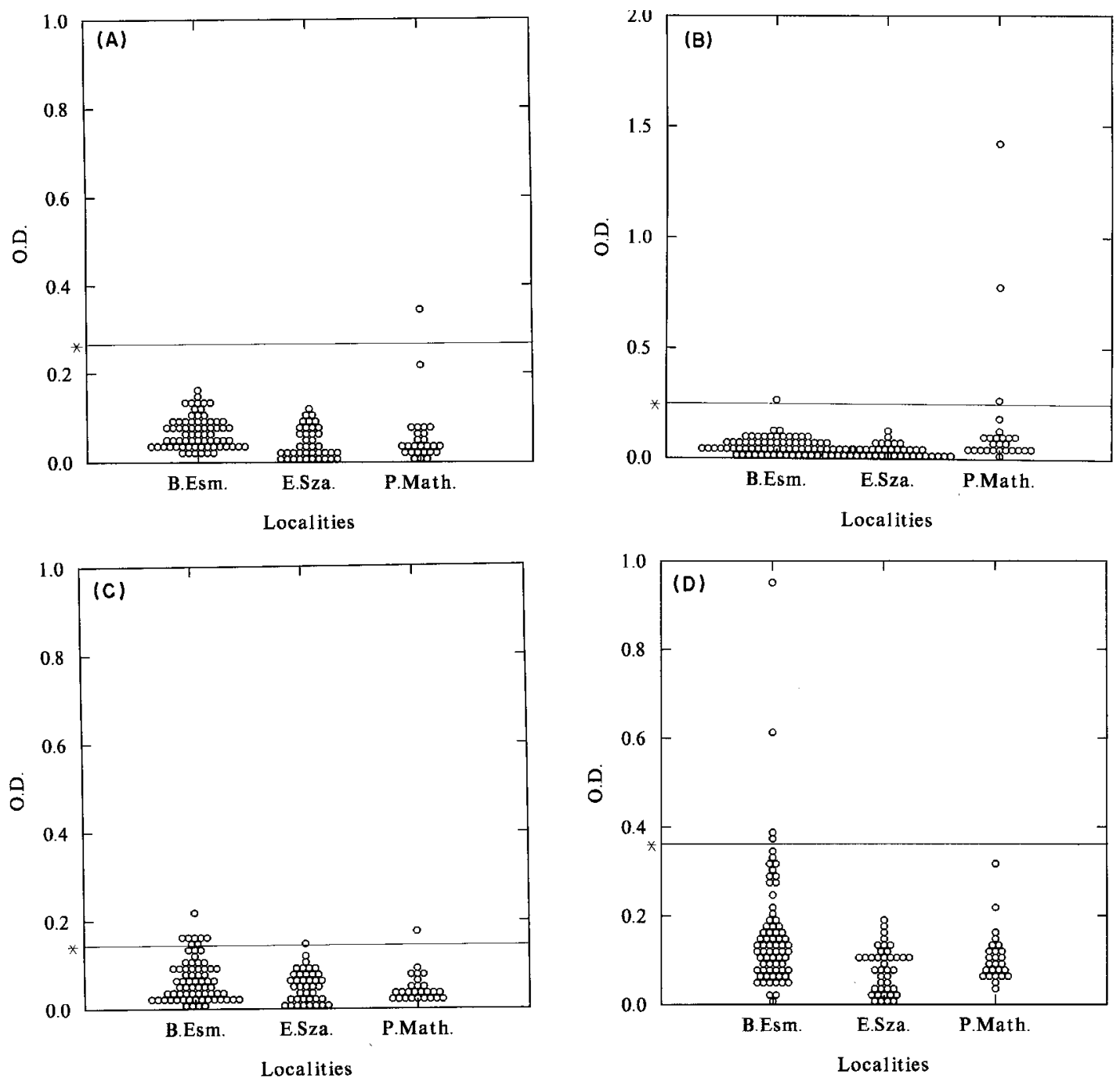

Fig. 6: results of Enzime Linked Immunosorbent Assay using circumsporozoite repeat peptides with the sera from Region 2, localities of Pai Mathias (P. Math.), Evangelista de Souza (E.Sza.) and Balneário Esmeralda (B. Esm.). Each circle represents an individual serum assayed with peptides of the (A) "classic"Plasmodium vivax (1/26 - 4\% in P. Math.), (B) P. malariae/ P. brasilianum (3/26 - 11\% in P. Math.; $1 / 70$ - 1.4\% in B. Esm.), (C) P. vivax VK247 (1/26 - 4\% in P. Math.; $1 / 40$ - 2.5\% in E. Sza.; $7 / 70-10 \%$ in B. Esm.), (D) P. vivax-like (4/70 - 6\% in B. Esm.). Cut off values are indicated by horizontal lines.

tory population, namely the home owners - this difference being more conspicuous in Juquiazinho than in Shangrilá. Recently, Abramo et al. (1995) have reported a low-rate IFAT false positive reaction for $P$. falciparum in sera of individuals with leishmaniasis, toxoplasmosis and Chagas' disease at 1:80 dilutions. Although no such data is available for $P$. vivax antigen and our area is not endemic for these diseases, we examined our data in light of this information. Overall positivity would drop from $28 \%$ to $20.5 \%$ if the 80 titer were adopted. These would still be high values for an area considered to be non-endemic for malaria.
It is noteworthy that most of the few autochtonous malaria cases reported in these regions by SUCEN, occured in home owners, who usually are only there on some weekends and vacations. This fact, together with the lower prevalence of anti-malaria antibodies in this part of the population, points towards a lower resistance against the infection by non-resident home owners, who are less exposed to contact with anophelines.

As mentioned before, only 5 malaria cases are included in our study. We did not have access to the remainder reported by SUCEN during the time 
span of our study, as outlined in Materials and Methods.

Results were not stratified according to patients' age, in view of the relatively low number of sera obtained in each locality.

Information gathered by submitting all study subjects to a rather comprehensive questionnaire failed to reveal the prior occurence of typical malaria symptoms. Most individuals only recalled incidences of "flu", with headaches and mild fever.

Similarly to our results, Mattos et al. (1993) found a few cases of extremely low parasitaemia, diagnosed as $P$. vivax, in six individuals in a nonendemic area, in the State of Rio de Janeiro, Brazil. Anti-plasmodial antibodies were detected in $65 \%$ of the sera collected from the local population. Blood from one of the patients, inoculated into a $S$. sciureus monkey, resulted in patent infection and spontaneous cure. Residual malaria was also found in the State of Santa Catarina and complete eradication was only achieved by treatment of all patients with a positive IFAT, irrespective of detection of patent parasitemia (Deane 1988).

A high prevalence of asymptomatic malaria has been reported mainly in Africa. In Brazil, there is evidence that asymptomatic or oligosymptomatic malaria cases may also occur in certain endemic areas (Prata et al. 1988, Silva et al. 1993, Malafronte et al. 1994). Arruda et al. (1989) in a seroepidemiological study of malaria in several Indian tribes in Brazil, found a high prevalence of anti-plasmodial antibodies, while parasites were only rarely found in their blood. A high prevalence of anti-P. malariae/P. brasilianum antibodies was found in monkeys, which were kept as pets. $P$. brasilianum is a simian parasite, believed to be identical or very closely related to the human parasite $P$. malariae (Lal et al. 1988a,b). The possibility of a low-grade monkey malaria affecting the Indian population was suggested. The occasional transmission of simian malaria to man has been described with extremely low parasitaemia and scarce symptoms (Contacos et al. 1963, Deane et al. 1966).

Cross-reactions between asexual blood forms of the several species of Plasmodium are common in IFAT. This test gives a broad indication of malaria prevalence. In contrast, repeat regions within the CS antigen of both $P$. falciparum and $P$. vivax are species specific. ELISA with a given CS repeat peptide reflects contact with sporozoites of the corresponding Plasmodium species, without necessarily resulting in circulating erythrocytic parasites. As for the anti-CS antibody results, obtained by using the different repeat peptides as antigen, the frequency of positive sera was not statistically different between permanent residents and home owners. This may be due to the fact that only a very small number of these sera were ELISA positive, so that the statistical analysis was less representative. However there were differences in the fine specificity of the P. vivax CS positive sera obtained from closely located areas. This was particularly conspicuous in the case of Shangrilá, where $17 \%$ of the sera reacted with the $P$. vivaxlike repeat peptide, compared to the absence of positive reactions with this peptide in Juquiazinho. With the P. vivax VK247 repeat peptide the positivity of these sera was $2.5 \%$ and $15 \%$, respectively. The sera of the five malaria cases were positive in IFAT, however all but one were negative in CS ELISA with all peptides tested.

Some years ago CS repeats of both $P$. falciparum and $P$. vivax were believed to be highly conserved in all geographically distinct isolates. The recent description of the two variants of the $P$. vivax CS, P. vivax VK247 (Rosenberg et al. 1989) and the human $P$. vivax-like parasite (Qari et al. 1993) may mean that other yet unknown variants could exist, accounting for the higher prevalence of anti-blood form parasite antibodies. Alternatively the lower prevalence of anti-CS antibodies could be explained by the fact that repeated challenges may be required to elicit stable anti-CS antibodies. This is documented by the greater prevalence of anti-CS antibodies in older groups, in malaria endemic areas (Nardin et al. 1979, Druilhe et al. 1986, Greenwood 1990). However anti-CS antibodies have also been reported to occur in primary infections (Fontes et al. 1991).

The human $P$. vivax-like parasite has a CS repeat which corresponds to the simian parasite, $P$. simiovale. Otherwise the identity of these parasites is not clear, since a line of the human isolates has not yet been obtained (Warhurst et al. 1993), and the clinical manifestations of this infection, as well as that of the VK247 variant are unknown. However, these variants are not restricted to areas of atypical malaria (Qari et al. 1991, Kremsner et al. 1992).

In our study area and also in Rio de Janeiro, there is a predominance of An. (Ker.) cruzii (Deane 1986, Forattini et al. 1986) with a higher density during the months of malaria transmission. In fact two specimens have recently been found infected by "classic" P. vivax among 1117 samples captured in Serra do Mar, and one by $P$. vivax VK247 among 1161 An. (Ker.) cruzii from Juquitiba (Branquinho et al. 1996). The susceptibility of An. (Ker.) cruzii to different malaria parasites remains to be studied. 
As for the P. malariae/P. brasilianum CS repeat $11 \%$ of the sera were positive in Pai Mathias, compared with $1.5 \%$ in Balneário Esmeralda. There is a very close similarity among $P$. malariae and $P$. brasilianum (a monkey parasite), in morphology (Deane 1992) and various other aspects. Monoclonal antibodies against $P$. malariae and $P$. brasilianum sporozoites cross-react with each other (Cochrane et al. 1984), and the amino acid sequence of the immunodominant epitope of the circumsporozoite protein is the same, in the two species (Lal et al. 1988a, b). Cochrane et al. (1990), reported the occurrence of a certain degree of crossreaction by ELISA, of the CS repeats of $P$. malariae/P. brasilianum and $P$. vivax VK247. This seems not to have occured in our case, since only four of our sera reacted with both of these peptides.

The significance of the high prevalence of antiblood forms antibodies in the individuals living in our study area, in view of the occurence of only very few cases of symptomatic malaria remains to be elucidated. We suggest that one of the possibilities might be the circulation of simian malaria parasites in human beings. This possibility will be further investigated.

\section{ACKNOWLEDGEMENTS}

To Dr Ruth Nussenzweig, from New York University, for supplying peptides as well as giving critical advice throughout the work. To Maria Stela Branquinho, Rosely dos Santos Malafronte and Lilian Ferrari for collaboration in field work. To Mauro Toledo Marrelli for assistance, Heitor Franco de Andrade for statistical analysis, Almir Robson Ferreira for map drawing. To Superintendência de Controle de Endemias of São Paulo and São Vicente for logistical support.

\section{REFERENCES}

Abramo CA, Fontes CJF, Krettli AU 1995. Cross-reactivity between antibodies in the sera of individuals with leishmaniasis, toxoplasmosis and Chagas disease and antigens of the blood-stage forms of Plasmodium falciparum determined by indirect immunofluorescence. Am J Trop Med Hyg 53: 202-205.

Arruda ME, Nardin E, Nussenzweig RS, Cochrane AH 1989. Sero-epidemiological studies of malaria in indian tribes and monkeys of the Amazon Basin of Brazil. Am J Trop Med Hyg 41: 379-385.

Branquinho MS, Marrelli MT, Curado I, Natal D, Barata JMS, Tubaki R, Carreri Bruno GC, Tironi R, Kloetzel JK 1996. Infecção do Anopheles (Kerteszia) cruzii por Plasmodium vivax e $P$. vivax variante VK247 nos municípios de São Vicente e Juquitiba, São Paulo. Bol Ofic Sanit Panam (in press).

Carvalho ME, Glasser CM, Ciaravolo RMC, Etzel A, Santos LA, Ferreira CS 1988. Sorologia de malária vivax no foco Aldeia dos Índios, município de Peruíbe, Estado de São Paulo, 1984 a 1986. Cad Saúde Públ Rio de Janeiro 4: 276-292.
Cochrane AH, Collins WE, Nussenzweig RS 1984. Monoclonal antibody identifies circumsporozoite protein of Plasmodium malariae and detects a common epitope on Plasmodium brasilianum sporozoites. Inf Immun 45: 592-595.

Cochrane AH, Nardin E, Arruda M de, Maracic M, Clavijo P, Collins WE, Nussenzweig RS 1990. Widespread reactivity of human sera with a variant repeat of the circumsporozoite protein of Plasmodium vivax. Am J Trop Med Hyg 43: 90-134.

Contacos PG, Lunn JS, Coatney GR, Kilpatrick JW, Jones FE 1963. Quartan-type malaria parasite of new world monkeys transmissible to man. Science 142: 676.

Deane LM 1986. Malaria vectors in Brazil. Mem Inst Oswaldo Cruz 81 (Suppl. II): 5-14.

Deane LM 1988. Malaria studies and control in Brazil. Am J Trop Med Hyg 38: 223-230.

Deane LM 1992. Simian malaria in Brazil. Mem Inst Oswaldo Cruz 87 (Suppl. III): 1-20.

Deane LM, Deane MP, Ferreira Neto J 1966. Studies on transmission of simian malaria and on a natural infection of man with Plasmodium simium in Brazil. Bull WHO 35: 805-808.

Druilhe P, Pradier O, Marc JP, Miltgen F, Mazier D, Parent G 1986. Levels of antibodies to Plasmodium falciparum sporozoite surface antigens reflect malaria transmission rates and are persistent in the absence of reinfection. Inf Immun 53: 393-397.

Ferreira AW, Sanchez MCA 1988. Malária humana: padronização e optimização de testes sorológicos para diagnóstico individual e inquéritos soroepidemiológicos. Rev Inst Med Trop S Paulo 30: 137 146.

Fontes CJF, Bathurst I, Krettli AU 1991. Plasmodium vivax sporozoite antibodies in individuals exposed during a single malaria outbreak in a non-endemic area. Am J Trop Med Hyg 44: 28-33.

Forattini OP, Gomes AC, Natal D, Santos JLF 1986. Observações sobre atividade de mosquitos Culicidae em matas primitivas da planície e perfis epidemiológicos de vários ambientes no Vale do Ribeira, São Paulo, Brazil. Rev Saúde Públ 20: 178-203.

Gadelha P 1994. From "forest malaria" to "bromeliad malaria": a case-study of scientific controversy and malaria control. Parasitol 36: 175-195.

Goldman IF, Qari SH, Millet PG, Collins WE, Lal AA 1993. Circumsporozoite protein gene of Plasmodium simium, a Plasmodium vivax-like monkey malaria parasite. Mol Bioch Parasitol 57: 177-180.

Greenwood BM 1990. Immune responses to sporozoite antigens and their relationship to naturally acquired immunity to malaria. Bull WHO 68 (Suppl.): 184190.

Kremsner PG, Neifer S, Zotter GM, Bienzle U, Rocha RM, Maracic M, Clavijo P, Nussenzweig RS, Cochrane AH 1992. Prevalence and level of antibodies to the circumsporozoite proteins of human malaria parasites, including a variant of Plasmodium vivax, in the population of two epidemiologically distinct areas in the state of Acre, Brazil. Trans $R$ Soc Trop Med Hyg 86: 23-27. 
Lal AA, De La Cruz VF, Collins WE, Campbell GH, Procell PM, McCutchan TF 1988a. Circumsporozoite protein gene from Plasmodium brasilianum. Animal reservoirs for human malaria parasites? $J$ Biol Chem 263: 5495-5498.

Lal AA, De La Cruz VF, Campbell GH, Procell PM, Collins WE, McCutchan TF 1988b. Structure of the circumsporozoite gene of Plasmodium malariae. Mol Bioch Parasitol 30: 291-294.

Malafronte RS, Valdívia JL, Nakaie CR, Kloetzel JK 1994. Seasonal variation of anti-RESA/Pf155 Plasmodium falciparum antibodies in three localities from the State of Amapá, Brazil. Rev Inst Med Trop S Paulo 36: 237-243.

Marques AC, Gutierrez HC 1994. Combate à malária no Brasil: evolução, situação atual e perspectivas. Rev Soc Bras Med Trop 27 (Suppl. I): 91-108.

Mattos MS, Oliveira-Ferreira J, Castro MG, Oliveira RL 1993. Malária autóctone no município de Nova Friburgo - RJ. IV Reunião Nacional dos Pesquisadores em Malária, Manaus, AM, Brazil. Proceedings, p. 23, Summary 13.

Nardin EH, Nussenzweig RS, McGregor IA, Bryan JH 1979. Antibodies to sporozoites: their frequent occurence in individuals living in an area of hyperendemic malaria. Science 206: 597-599.

Pessi A, Michel M, Bianchi E, Mendis A, Tougne C, Verdini AS, Lambert PH, Carter R, Mendis K, Del Giudice G 1990. Use of synthetic peptides in the study of the antibody to Plasmodium vivax sporozoites. Am J Trop Med Hyg 42: 17-23.

Prata A, Urdaneta M, McGreevy PB, Tada S 1988. Infrequency of asymptomatic malaria in an endemic area in Amazonas, Brazil. Rev Soc Bras Med Trop 21: 51-54.

Qari SH, Goldman IF, Povoa MM, Oliveira S, Alpers MP, Lal AA 1991. Wide distribution of the variant form of the human malaria parasite Plasmodium vivax. J Biol Chem 266: 16297-16300.

Qari SH, Shi Y, Goldman IF, Udhayakumar V, Alpers MP, Collins WE, Lal AA 1993. Identification of Plasmodium vivax-like human malaria parasite. Lancet 341: 780-783.

Rosenberg R, Wirtz RA, Lanar DE, Sattabongkot J, Hall T, Waters AP, Prasittisuk C 1989. Circumsporozoite protein heterogeneity in the human malaria parasite Plasmodium vivax. Science 245: 973-976.

Silva RSU, Santos ECO, Loureiro ECB, Jesus IM, Camera VM, Brabo EES, Fernandes AS, Souza DM 1993. Malária assintomática - uma das causas da perpetuação da cadeia de transmissão da malária. IV Reunião Nacional de Pesquisadores em Malária, Manaus, AM, Brazil. Proceedings, p. 31, Summary 21.

SUCEN - Superintendência de Controle de Endemias 1990. Relatório anual de avaliação do Programa de Controle da Malária no Estado de São Paulo, São Paulo, 52 pp.

SUCEN - Superintendência de Controle de Endemias 1995. Avaliação do Programa de Controle de Malária. Estado de São Paulo - período de 1992 a 1994, 54 pp.

Tauil PL 1986. Comments on the epidemiology and control of malaria in Brazil. Mem Inst Oswaldo Cruz 81 (Suppl. II): 39-41.

Warhurst DC, Tucker JM, Povoa MM, Green PJ 1993. Unusual Plasmodium related to $P$. simiovale. Lancet 341: 1408.

Wilkerson RC, Peyton EL 1991. The Brazilian malaria vector Anopheles (Kerteszia) cruzii: Life stages and biology (Diptera: Culicidae). Mosquito System 23: 110-122.

Zavala F, Tam J, Masuda A 1986. Synthetic peptides as antigens for the detection of humoral immunity to Plasmodium falciparum sporozoites. J Immun Meth 93: 55-61. 
244 Malaria Serology in Low Endemicity Area • Izilda Curado et al. 